\title{
Analysis of Village Fund Allocation (ADD)Management in Lawang Agung Village Rupit District, North Musi Rawas Regency
}

\author{
Miki Indika ${ }^{*}$, Suharto Patih ${ }^{1}$, and Septarina Widyawati ${ }^{1}$ \\ ${ }^{1}$ Program Studi Akuntansi Fakultas Ekonomi Universitas Musi Rawas, Lubuklinggau, \\ Indonesia
}

*Corresponding author: miki.unmura@gmail.com

\begin{abstract}
The aim is to see the Village Fund Allocation Management in Lawang Agung Village Rupit District, North Musi Rawas Regency. This research included qualitative research. The operational variable of this research was the Management of Village Fund Allocation with Indicators for planning, implementation, administration, reporting, and accountability. Secondary data in the form of agency profiles and Village Fund Allocation documents. The data analysis technique used is qualitative descriptive analysis. The results showed that the Village Fund Allocation Management planning stage in the Lawang Agung village is not yet fully the community's expected needs at that time. The implementation phase of the Village Fund Allocation, there was a delay of more than one week even though the working time was only 5 days in preparing several documents. So that it made delays in administration, reporting, and accountability. The Village Fund Allocation Administration stage, due to the delay in reporting form activities in the field, had an impact on delays in closing the books which result in late submission of accountability reports to the Village Head, and it had an impact on the delay in reporting to the District and District. The Village Village Fund Allocation reporting stage, the reporting stage also occurs due to delays due to delays in the implementation phase so that the impacts on delay in the administration and reporting delays on the District and District parties. For the accountability phase of the Village Fund Allocation, it was timely that the accountability report was made and reported monthly, 31 December. But the accountability report of the village government was not informed to the community. Therefore it had been no direct accountability to the community with the management of the Village Fund Allocation in Desa Lawang Agung, Rupit District, North Musi Rawas Regency.
\end{abstract}

\section{Introduction}

The smallest unit of Indonesia's supremacy system is "village". Its function, role, and contribution fill a strategic post. For some reasons, stakeholders and bureaucracy put more concern to it because most of Indonesia people live in the rural area and the problems those expand and arise from this post must have been settled. Therefore "village" deserves considering as a relevant prosperity standard of a nation [1] Village act Number 6 of 2014 states that a village or customary village is a law community that authorizes territory, local government, and community sake in accordance to respected community right stated in Indonesia supremacy system. Village is the pillar for distributing the program of the central government by Village act Number 6 of 2014 about authorization including local good governance, organization, finance, and village empowerment. As the realization of 
supporting Act number 6 of 2014, village revenue comprises seven sources include: (a) Village revenue is obtained from village enterprise, village asset, self-subsistent and participation, cooperation (Gotong Royong), and other's village revenue; (b) State Budget (APBN); (c) Local Tax and Local Retribution of Regency level; (d) Balancing fund (Dana Perimbangan); (e) The grant from State and Regional budget; (f) The bequest from a third party; and (g) Another legal village revenues

This regulation demands local government to allocate balancing funds in the form of Village Fund Allocation (ADD) by considering the fairness principle through equity. Balancing fund refers to Act number 6 of 2014 article 72 clause 4 if balancing fund is unrealized, strict sanction held in accordance to article 72 clause 6 , the government can postpone and cut the balancing fund deducted by private fund allocation. In government regulation (PP) number 43 of 2014 revised to government regulation number 47 of 2015 about the implementation of Act number 6 of 2014 about "village" article 96 clause 3, Village Fund Allocation is distributed by considering the numbers of people, poverty level, territory, and geography level. Village Fund Allocation can't be separated from village budget (APBDes) management. The entire events taken from Village Fund Allocation must be planned implemented and evaluated by the community. All events must be charged administratively, technically, and legally. Village Fund Allocation is stated in Regent Regulation of North Musi Rawas Regency number 683/KPTS/DPMD-P3A/MRU/2018 about technical guidance of realization Village Fund Allocation, Village Fund, and Village Grant for Underdeveloped Village for 2018.

Village Fund Allocation (ADD) is a financial relationship form at the levels of government, including the district government and the village government. To formulate appropriate finance, it is necessary to have an understanding of village government authority. Thus the government budget given to the villages is entirely used for village development and facilities. The funds must be used appropriately with the regulations to increase village development, community participation, and implementing the village grant in the future [2]

As a pillar of regional autonomy, villages need balanced funding in improving regional development. The North Musi Rawas Regency government hopes allocation of village funds, community-based participatory planning will be more sustainable, because the community can be directly involved in making planning documents in their village and participate in realizing it. Based on the author's preliminary observations, information was obtained from the community about problems and obstacles faced by the management of Village Fund Allocation (ADD) in Lawang Agung village, Rupit District, North Musi Rawas Utara Regency. At the planning stage. The program was strikingly arranged by the village head, not from the Village deliberation level. At the stage of discussion, there is no transparency in making the draft of the development plan because every meeting is only attended by certain people without involving the community. This phenomenon will have an impact on planning, implementation, administration, reporting, and accountability for the management of Village Fund Allocation (ADD) in Lawang Agung Village, Rupit District, Musi Rawas Utara Regency. Based on the background above, the researcher took the research title "Analysis of Village Fund Allocation Management in Lawang Agung Village Rupit District, Musi Rawas Utara Regency".

\section{Methods}

The data used in this study are primary data and secondary data. Primary data is any information related to Lawang Agung Village, Rupit District, Musi Rawas Utara Regency from the results of interviews, while secondary data is in the form of related functions such as documents and reports on the management of Village Fund Allocation. The data collection method used in this research is the interview method by asking structured and unstructured questions using obtain broad information about the object of research. Observation and survey are directly observing the activities held by Lawang Agung Village Government. In this study, the data analysis used is qualitative analysis through a non-statistical analysis. The data obtained in the form of numbers and tables were then interpreted properly including theories to explain the phenomenon. The analysis technique used by this research is descriptive analysis technique through explaining the theories not numbers 


\section{Results and Discussion}

The management principle of Village Fund Allocation (ADD) including financial management of Village Fund Allocation (ADD) is an integrated part of village financial management in Village Budget; all activities must be accounted for administratively and technically by regulations. Village Fund Allocation. (ADD) is used sparingly, purposefully, and in control. Village financial management is stated in Government Regulation Number 113 of 2014 about Guidelines of Village Financial Management and specifically regulated in Regent Regulation Number 30 of 2016 about Village Financial Management in North Musi Rawas Regency.

For 2018, Lawang Agung Village, Rupit District, North Musi Rawas Regency receives Village Budget (APBDesa) comes from the Regional Budget consisted of (Tabel 1).

Tabel 1. Anggaran Pendapatan Dan Belanja Desa (APBD desa) Desa Lawang Agung Anggaran Tahun 2018

\begin{tabular}{clr}
\hline No & \multicolumn{1}{c}{ Sumber Dana } & Jumlah (Rp) \\
\hline 1 & Dana Desa (DD) & $926.853 .000,00$ \\
2 & Alokasi Dana Desa (ADD) & $530.885 .155,00$ \\
\hline \multicolumn{2}{c}{ Total } & $1.456 .885 .155,00$ \\
\hline
\end{tabular}

Sumber: APBDesa Kabupaten Musi Rawas Utara.

The total funds were obtained from the Lawang Agung Village Budget (APBDesa), Rupit District, North Musi Rawas regency of 2018. This Village Government manages the Village Allocation Fund (ADD) of IDR $530,885,155.00$. The operational cost is $30 \%$ or IDR $159,265,547.00$ and for the empowerment of the village, the community is $70 \%$ or IDR $371,619,608.00$. Village Fund Allocation (ADD) is an integrated part of village financial management in the Village Budget (APBDesa) because all activities must be accounted for administratively and technically by regulations. Lawang Agung Village Government in managing the Village Fund Allocation (ADD) can be seen in the following stages consisting of planning, implementation, administration, reporting, and accountability. The discussion of each stage is as follows:

Village Fund Allocation Planning. At the planning stage, the Village Fund Allocation (ADD) management activity or the Lawang Agung Village ADD program has not been realized by the Minister of Home Affairs Regulation Number 113 of 2014 and the Regent Regulation Number 35 of 2018. The planning of Village Fund Allocation (ADD) is not capturing the aspirations and village needs through village deliberations. The planning step in Lawang Agung village started from village deliberation held by the Lawang Agung Village Government followed by the BPD, but community involvement was very limited. The implementation of this deliberation is aimed to discuss the RPD of 2018. The Village Fund Allocation Budget received by the Village Government of Lawang Agung of 2018 is IDR 530,032,155.00. At the implementation stage RPDhas been drafted and followed up and must be agreed upon at the latest October of the current year, then an Evaluation of the RPD in the Village Budget is held by Regent through sub-district head at the latest three days after the agreement. RPD must be evaluated and verified at the latest 20 working days since the village budget draft is accepted. If it has been appropriate, RPD included in the village budget must be stipulated by Village Head and BPD.

1. Implementation of Village Fund Allocation

At the implementation stage of the Village Fund Allocation (ADD) management activity or programs has not yet been realized by the Minister of Home Affairs Regulation Number 113 of 2014 and the Regent Regulation Number 35 of 2018. A team is formed to manage activities or programs. The management process is led by PTPKD and Treasury. Both PTPKD and treasurer are directly elected by the Village Head and assisted by community empowerment institutions in the village. The implementation of village financial management begins with the process of disbursing funds through 
Sumsel Babel Bank, Rupit Branch, next third party and colleague are invited by the village government to receive funds in accordance to (DRKDesa). The process of withdrawing the funds consisting of 3 (three) stages, Phase I in April by 40\%, Phase II in August by 40\%, and Phase III in October by $20 \%$. In the planning process, the Village Treasurer experienced a delay of more than one week in preparing several documents; this was because the document attachments were incomplete so they could not be verified. This greatly affects the stages of the administration, reporting, and accountability. Village Budget (APBDesa) Report for 2018, the amount of the Village Fund Allocation (ADD) budget is Rp. 530,032,155, and the realization of revenue of Rp. 470,032,155. The amount of the expenditure budget is IDR 436,602,155.00 and the amount of the realization of the expenditure is IDR 375,032,155, there is a deficit of IDR 1,570,000.00 (One Million Five hundred and seventy thousand rupiahs). Although in the process of the implementation stage, there was a delay in the disbursement process due to incomplete documents the implementation of the Village Fund Allocation activities is still ongoing.

Administration of Village Fund Allocation. At the administrative stage, the Village Fund Allocation (ADD) management activity or the Lawang Agung Village ADD program has not yet been realized by the Minister of Home Affairs Regulation Number 113 of 2014. In Lawang Agung Village, Rupit District, Musi Rawas Utara District, the administration is carried out by the Village Treasurer, as the result of delayed activities in the field, late submission of reports occurs to the Village Head at the end of every month, it has an impact on in reporting accountability Village Head to District and Regency parties. The cycle of village financial administration (Village Fund, Village Fund Allocation, Tax Revenue Sharing and Retribution) as follows:

1) The village financial administration cycle begins with the stipulation of the Village Budget through Village Treasurer

2) Based on the Village Budget (APBDesa), the village government conducts financial transactions in the form of cash receipts as a source of village income and makes cash disbursements to run village operations and programs

3) The village treasurer is required to record every transaction of cash receipts and cash disbursements based on valid notes of financial transactions (cash in and out), especially a Request for Payment and Receipt of Cash, record them in treasury books

4) The village treasurer is required to close (close the book) at the end of each month and report it to the village head

5) The Village Treasurer posts every transaction recorded in the treasury book of each account into the general ledger.

6) When compiling financial reports, both semester and yearly, the village treasurer must prepare a summary balance of each account.

7) The Village Treasurer calculates and makes adjustments to accounts related to current assets as the stage of preparing the village-owned wealth report

8) The Village Treasurer is obliged to compile a financial report as an accountability report

9) The accountability report is submitted monthly to the village head at the latest of 10th of each following month

10) Administration of revenue and expenditure must use a general treasury book, tax book, and bank account book.

Reporting. At the reporting stage, the Village Fund Allocation (ADD) management activity or the Lawang Agung Village ADD program has not yet been realized by Minister of Home Affairs Regulation Number 113 of 2014 and Regent Regulation Number 35 of 2018. Reporting is one form of accountability carried out by Lawang Agung Village Government in particular. In Lawang Agung Village, the reporting system is carried out substantially and normatively. Substantially, the village government reports every 3-4 months through deliberations conducted by the village government and colleagues. This report eased the evaluation of programs or activities financed by the Village Fund 
Allocation (ADD). Delays in the implementation stage affect reporting stages as well as accountability. The village government is obliged to report every activity or program financed by the Village Fund Allocation (ADD) by making a report of Accountability Letter (SPJ) to the Regency with approval contained a list of activities funded by the Village Fund Allocation (ADD) and anything related to programs funded by the Village Fund Allocation (ADD). The village head submits the village budget (APBDes) realization report to the Regent in the form of a first-semester report and a year-end semester report. The first-semester report is submitted at the latest end of July. And year-end semester report is submitted at the latest end of January. Village Head as the head of the operational team is required to make a semester report and Annual Village Fund Allocation Report (ADD) to the Regent through sub district head, including the development of implementation, absorption of funds, the problems faced and the final results of using the Village Fund Allocation (ADD). Submission of Semester Reports and Annual Reports is a structured report from the operational team to the assistance team and then recapitulated and reported to the Regent. Semester reports from the operational team must be submitted at the latest $10^{\text {th }}$ July, but the operational Team is late for the submission of the first semester reports.

Accountability. In the accountability stage, the Village Fund Allocation (ADD) management activity or the Lawang Agung Village ADD program has not yet been realized by the Minister of Home Affairs Regulation Number 113 of 2014 and Regent Regulation Number 35 of 2018. The stage of accountability started from Head of Lawang Agung Village to the North Musi Rawas Regent, through the Head of Rupit Sub-District, by making a Village Government Administration report (LPPDes) consisting of income, expenditure, and financing. The form of accountability in the implementation of village financial management, in this case, includes reports on the realization of the use of Village Fund Allocation (ADD) in Lawang Agung Village Rupit District, North Musi Rawas District, comprising all village financial income and expenditure transactions, must be accounted for by the Village Treasurer as follows:

1) Making expenditure accountability reports by attaching a general cash book, tax revenue cash book, bank account book.

2) The accountability report must be submitted a copy to Rupit District and the original one copy as the archive of the village government

3) The report is prepared to account for the previous stages and the previous month

4) The accountability report is submitted simultaneously with the submission of SPP Village Budget stage II (accountability stage I) and stage III (Accountability stage II) SPP fixed income and allowances for the Village Head and Village Officials, as well as BPD allowances for the month (Accountability of the previous month)

5) Accountability stage III report must be submitted at the latest January $31^{\text {st }}$ of the following year.

Following explanations are the successes, challenges, obstacle, and supporting factors in the management of Village Fund Allocation (ADD) in Lawang Agung Village, Rupit District, Musi Rawas Utara Regency:

Success:

a. Able to increase community participation in Village Deliberation

b. There must be a synergy between the village government and its partners such as the BPD, Community Empowerment Institutions, and other Traditional Institutions

c. The Village Government build infrastructure development from the Village Fund Allocation (ADD)

d. The amount of self-subsistent community

e. There are transparency and responsiveness from the village government

Challenge:

a) It is necessary to form BUMDes by seeing village potencies, such as credit unions or other businesses.

b) There needs to be an activity or activity in the economic sector 
c) With the existence of activities in the economic sector, it is hoped that it will absorb local workers

d) Discipline in reporting needs to be further improved for the sustainability of the Village Fund Allocation (ADD) program.

e) Taking precedence to primary program or activity

f) Program classification must be carried out appropriately so that the program can be implemented and right on target

Obstacles:

a) Apparatus Capability

It is known that human resources influence Village Fund Allocation Fund (ADD) management and administration

b) Limited Village Fund Allocation Fund (ADD).

Limited fund influences the programs and activities that proposed by the village government, a lot of programs and activities cannot fully be funded by Village Fund Allocation (ADD).

c) Lack of discipline

In the reporting process, sometimes expenditure notes for the Village government are not submitted even lost not submitted to treasury.

Supporting factors:

a. Communication

Communication in government administration is extremely important. In Lawang Agung Village, the communication that exists between the village government and work partners runs well. It is proven by a positive response between village government and colleague.

b. Self-subsistent Community

It has become one of the most important factors in succeeding programs or activities. Also, it supports the activity or program which can't be fully funded by Village Fund Allocation (ADD).

c. Facilities and infrastructure

Facilities and infrastructure are very useful in carrying out the duties of the village government. With sufficient office equipment, management of Village Fund Allocation (ADD) becomes easier. In addition, a deliberation room is also an important factor in supporting the activities and program provided by Village Fund Allocation (ADD).

\section{Conclusions}

Based on the results, it can be concluded that Village Fund Allocation (ADD) Management in Lawang Agung Village Rupit District, North Musi Rawas Regency of 2018, as follows: at the planning stage, Village Fund Allocation management in Lawang Agung Village is not fully implemented by the community needs and village deliberations because of its lack of community participation; at the implementation stage, Tardiness in preparing documents happened because the document attachment in the form of expenditure was not complete yet so it could not be verified and giving impact to administration, reporting, and accountability; at the administration stage, due to delays in reporting activities in the field giving impact on submission of accountability reports; at reporting stage, the delay occurs because of administration stage tardiness and at the accountability stage, the accountability report is punctually reported every month on December $31^{\text {st }}$. However, it was not transparent information and it was not announced to the village community.

\section{REFERENCE}

[1] Andi Siti Sri Hutami.2017. Analisis Pengelolaan Alokasi Dana Desa diDesa Abbatireng Kecamatan Gilireng Kabupaten Wajo. Universitas Hasanuddin Makasar

[2] Sri Lestari. 2017. Analisis Akuntabilitas Pengelolaan Alokasi Dana Desa di Wilayah Kecamatan Banyudono. Universitas Muhamadiyah Malang

[3] Chabib Soleh dan Heru Rochmansjah, 2015.Pengelolaan Keuangan Desa. Bandung: Fokus Media 
[4] Danang Sunyoto. 2016. Methodologi Penelitian Akuntansi. Bandung : PT Rafika Aditama

[5] Keputusan Bupati Musi Rawas Utara Nomor 683/KPTS/DPMD-P3A/MRU/2018 Tentang Pedoman Teknis Pelaksanaan Penggunaan Alokasi Dana Desa, Dana Desa, Dan Tambahan Bantuan Keuangan Pemerintah Kabupaten Kepada Pemerintah Desa Khusus Desa Tertinggal Tahun Anggaran 2018

[6] Peraturan Menteri Dalam Negeri Republik Indonesia Nomor 13 Tahun 2014 Tentang Pedoman Pengelolaan Keuangan Desa

[7] Prodi Akuntansi, Fakultas Ekonomi, 2017. Pedoman Penulisan Proposal Penelitian dan Skripsi.Lubuklinggau : Universitas Musi Rawas

[8] Sugiyono, 2013.Metode Penelitian Administrasi. Bandung : Alfabeta, CV

[9] Undang-Undang Republik Indonesia Nomor 32 Tahun 2004 Tentang Desa 